\title{
A Model of University Reform in a Developing Country: The Brain Korea 21 Program
}

\author{
Sung-Soo Seol
}

Published Online Date: May 1, 2012

\begin{abstract}
This paper is a review of a 13-year-old policy for university reform in Korea, the Brain Korea 21 Program, based on current theoretical frameworks. Current theoretical frameworks are classified into three groups: micro and macro perspectives on universities and discussion on world-class universities. The overall purpose of BK21 is to bring up high-level scholarship through manpower and achieve several targets of university reform. The program can be evaluated as a success in terms of following a research university model but not the entrepreneurial university model. However, the fact that a 13-year old policy developed under a research university model had features of the entrepreneurial university shows the direction of change that the research university is currently undergoing.
\end{abstract}

Keywords University capitalism, university entrepreneurism, world-class university, Brain Korea 21 Program

\section{Introduction}

Is university reform an internal issue only for university members, educational experts or educational policy makers? Are the issues about university graduates and research outputs only within the confines of university boundaries? Many studies on university reform have been based on the viewpoint of universities and from an educational perspective. The trend is that there is a strong discussion on university capitalism or university entrepreneurism ever since Slaughter \& Leslie (1997) and Clark (1998) advanced papers, both coming from advanced countries.

In fact, American universities have been entrepreneurial dating back to the Bayh-Dole Act of 1980, which allowed the ownership of patents generated from Federal research to be used by universities. (Rothaermal, Agung \& Jiang

\footnotetext{
* Professor, Department of Economics, Hannam University, Daejeon, Korea, 306-791 (s.s.seol@hnu.kr)
} 
2007) In addition, the financial crisis of universities because of long recessions and the cut down of research funds from the Federal government after the Cold War forced research universities to make structural changes to achieve selective excellence and enter into entrepreneurial activities. (Barrow, 1996)

Before further discussion, let us remember the root of American research universities, which are models of entrepreneurial change to nearly all universities worldwide. The history of the American research university began with Johns Hopkins University in the 1880s and also from the early 16 member universities of the Association of American Universities set-up in 1900. All of them are current leading universities and most of them are private. (Geiger, 1986; 1993, 2004)

Most studies from developing countries on university reform are focused on the role of universities in the developing process of each country. The basis of research and research infrastructure in universities of developing countries are weak compared to developed countries. Realistically, innovative research does not exist in many developing countries.

This paper wants to evaluate past policies for university reform on a developing country in light of current theoretical frameworks. The inception time of the Brain Korea 21 Program is nearly identical to the development of theoretical frameworks for academic capitalism or entrepreneurism, but still precedes the discussions on the world-class university. The BK21 program made no significant references to discussions of the entrepreneurial university. Therefore, a review of the 13-year-old policy in light of current theoretical frameworks will be a good case for identifying the relationship between theory and policy and for further designing a policy on university reform.

\section{Current Theoretical Frameworks}

\subsection{Micro Perspective}

A micro perspective on university reform represents theoretical discussions about the changing shape of university in terms of status, culture, management, and activities of the university. This includes the theoretical framework on academic capitalism (Slaughter \& Leslie, 1997) and university entrepreneurship (Clark, 1998; Sporn, 2001, Etzcowitz et al., 2000; Etzkowitz, 2004; Bercowitz \& Feldman 2006; Wong, 2007; Rothaermal, Agung \& Jiang, 2007; Guerrero, Urbano, 2010; Mars \& Cecilia, 2010).

Rothaermal, Agung \& Jiang (2007) reviewed 173 articles on university entrepreneurship during 1981-2005. Most studies have appeared from late 
1990s, and there were 50 papers alone in the special editions of 11 academic journals during the first half of 2000 . The issues can be classified into four groups: the entrepreneurial research university, new firm creation, environmental context including networks of innovation, and productivity of technology transfer. Studies indicate that mostly universities were concerned with this framework until the first half of 2000 .

The basic mission of traditional universities is teaching and research, but currently the new mission of entrepreneurship has been included. Academic capitalism is characterized by autonomy from government and university institutions, entrepreneurial activities to attract funding, system based on meritocracy, entrepreneurial education, and education based on demand.

University entrepreneurism first appeared from research universities, but now the trend has expanded to general universities. Yokoyama (2006) reviewed five universities from the UK and Japan and classified the entrepreneurism of universities into five types by the degree of entrepreneurship: prototype, entrepreneurial-oriented university, fledging entrepreneurial university, adaptive entrepreneurial university, and ideal type. Guerrero and Urbano (2010) reviewed Spanish universities and classified university entrepreneurialism simply into three stages: initial, development, and consolidation.

Sporn (2001) identified seven critical factors of the entrepreneurial university such as an environment triggered by crisis or opportunities, clear mission, entrepreneurial culture, differentiated structure, professionalized management, shared governance, and committed leadership. 10 years later, Guerrero and Urbano (2010) also identified critical factors for university entrepreneurialism in two dimensions based on data analysis: missions, governance, and organization structures; support measures, entrepreneurial education, and attitude to entrepreneurialism; incentives for environmental factors, human resources, and alliance; as well as entrepreneurial activities as resources and capabilities in entrepreneurialism.

\subsection{Macro Perspective}

A macro perspective on universities is the study on the role of universities to a nation's innovation and social and economic development. Some of the frameworks include new growth theory of economics, systems of innovation, framework of the Mode 2 knowledge production, and the Triple-Helix model of innovation. Reddy (2011) clearly mentions three theoretical frameworks recognizing the importance of universities to economic development: systems of innovation, Mode 2 Society, and Triple Helix. All of the theoretical discussions emphasize universities as the center of knowledge production in a knowledge-based economy.

Theory on the systems of innovation stems from the 1980's Japanese study by Freeman (1987) followed by Lundvall (1992) and Nelson (1993). 
Freeman identified the systemic difference of Japan and its impact on innovation. The notion of nationwide systems of innovation has expanded to regional innovation systems (Cooke, 1998) and sectorial systems of innovation (Bresch, Malerba, 1997). As any system, this identification contains elements of systems, critical factors, and key actors. The essence of this theory can be summed by realizing innovation is not an isolated phenomenon of the firm. Rather innovation is an output supported by various networks of actors and institutions such as industry, universities, and even financial institutions. Second, universities are the birthplace of new knowledge and technology.

The Mode 2 knowledge production system is a new paradigm towards multidisciplinary, application-orientated knowledge production with a social accountability of universities as opposed to the traditional Mode 1 view of knowledge production as being discipline-based, basic research orientated, and of taking place in isolation from society. (Gibbons et al., 1994) Moreover, the basis of Mode 2 knowledge production led to the Mode 2 society. (Gibbons, 2000; Godin \& Gingras, 2000) Although Pavitt (2000) criticized the Mode 2 based on the importance of basic research that should be emphasized, there is no evidence that basic research has deteriorated and weakened, but rather there is clear evidence that university entrepreneurism has deepened and expanded. (Rothaermal, Agung \& Jiang, 2007)

Theoretical framework of the Triple-Helix is based on the universityindustry-government linkage for evolving innovation. The framework, however, is not only the relationship, but also for the evolving of each institution. (Etzkowitz, Leydesdorff, 1997) The framework is based on three parts: institutional transformation, evolutionary mechanism, and to the second academic revolution. Accordingly, the university is at the core center of this relationship and has a mission towards economic development. Etzkowitz, Leydesdorff (2000) suggest that the Triple-Helix overlay can be a model to explain the social structure of Mode 2.

\subsection{World-Class University}

The discussion of world-class universities (here after WCU) has begun shortly after that of university entrepreneurialism. (Altbach, 2004; Altbach \& Balan, 2007; Huisman, 2008; Mohrman, 2008; Mohrman, Ma \& Baker, 2008; Salmi, 2009; Yang and Welch, 2011, Liu, Wang \& Cheng, 2011) World-class universities are defined as being famous and prestigious in academics around the world. They are fundamentally research universities, which are key institutions for development of society by the production and distribution of knowledge in the $21^{\text {st }}$ century. (Van der Ploeg \& Veugelers, 2008; Ramakrishna \& Krishna, 2011) In addition, the prestige of being a WorldClass University is often used for further funding. (Potts, 2011) 
This discussion has largely been due to the announcement of academic rankings, such as the Academic Ranking of World Universities by the Shanghai Jiao Tong University of China from 2003, THE World University Rankings by the Times from the United Kingdom from 2004, and currently QS World University Rankings by the Quacquarelli Symonds of the United Kingdom, who previously collaborated with THE Rankings. Also, the US News and World Report, which is famous for the rankings of US universities, has announced the US News World Best Universities, which is actually the QS ranking system. Although there are many critics, world rankings has been widely accepted by all research universities.

WCU is sometimes defined simply as the top 100 universities. Hence, they are located in developed countries, which has more than 25,000 US dollars per capita GDP. (Liu, 2007) In the Shanghai Jiao Tong Ranking of 2011, most universities are from the USA, Canada, Australia, and Europe, and some universities in Japan and Israel also made the top 100. In the Times Ranking of 2011, Asian universities from Japan, China, Korea, Hong Kong, and Singapore were included.

Table 1 Location of the World Top 100 Universities

\begin{tabular}{|c|c|c|}
\hline Announcer & Main Region & Asia \\
\hline $\begin{array}{l}\text { Shanghai } \\
\text { Jiao Tong }\end{array}$ & \multirow{3}{*}{$\begin{array}{c}\text { North } \\
\text { America, } \\
\text { Europe, } \\
\text { Australia }\end{array}$} & Japan, Israel \\
\hline The Times & & $\begin{array}{l}\text { Japan, Hong Kong, China, Korea, } \\
\text { Singapore }\end{array}$ \\
\hline QS & & $\begin{array}{l}\text { Japan, Hong Kong, Korea, Singapore, } \\
\text { China, Taiwan }\end{array}$ \\
\hline
\end{tabular}

\subsection{Relationship between Theoretical Frameworks}

Academic capitalism can be said to be the change of the university towards the market, and university entrepreneurism can be known as the changing shape of the university towards industry, although both concepts are generally used interchangeably.

As for the macro perspectives on universities, the framework on national systems of innovation emphasizes the importance of universities to a nation's competiveness. The discussion of Triple-Helix can be conceptualized as "how to mobilize" a national systems of innovation. The framework for Mode 2 production shows that the nature of knowledge production in universities is multi-disciplinary and application oriented. Specifically, the Mode 2 framework can be the basis of university entrepreneurism and academic capitalism can be a part of the Triple-Felix mechanism.

On the surface, the discussion on the WCU does not seem to relate to the micro and macro frameworks laid out. The Times Higher Education rankings 
apparently uses an index for research earnings, but, more importantly the WCU framework is deeply embedded on a twofold macro understanding; Universities are the centers of knowledge production and the best knowledge means the best national competiveness.

\section{The model in late 1990 s Korea}

\subsection{Background of the Model}

Korean university policies had largely focused at the undergraduate level and no intensive policy for graduate school appeared until the Brain Korea 21 Program in 1999. The 21 in BK 21 mean a policy for the $21^{\text {st }}$ century. A previous notable policy for university reform includes the freedom of the establishment of universities and colleges in 1995. Since then, students in tertiary education have dramatically expanded representing an enrollment ratio of about $80 \%$ of high school graduates.

In 1997, the Korean government recognized the severity of a lack of research by universities. There were 9,444 papers listed in the Science Citation Index (SCI) and the SCI-Expanded in 1998, ranking Korea $18^{\text {th }}$ in the world. Korean universities' research output was 3.9\% of the United States, $13.8 \%$ of the United Kingdom, and $15.2 \%$ of Japan. A simplified sign of weakness was that the number was only $82 \%$ of Japan's two universities. (Ministry of Human Resources, 2006) International papers had grown very quickly in absolute numbers since the early 1970s, but the Korean government recognized the severity in difference comparing Korean universities to international universities and especially in comparison with universities from advanced countries. In the early 1970s, the numbers of SCI papers were only several dozen in the whole nation. (Chung, Seol, 2010)

Because of Korea's historical lack of research, a seven-year program for graduate schools, the Brain Korea 21 Program, was launched in 1999. The vision of the program was towards increasing competition and cooperation suitable for a knowledge-based society. The program was designed under four principles: select and concentration, fostering the next generation, linkage to university reform, and balanced regional development. (Ministry of Human Resources, 2007)

\subsection{Model of Grants}

The purpose of the program is complex. The official goal was "fostering world-class manpower" by supporting graduate students, but it had multipurposes such as university reform through a cut-down of undergraduates, 
building world-class research capabilities and universities, building university and industry relationships, and building regional research bases. Simply speaking, the goal could be expressed as one official purpose and four strategies to achieve that purpose.

Targets of the program are only graduate students and post-docs, but they have to be affiliated with a selected professor's unit. For example, grants are given to certain units, allocating $45 \%$ for scholarships to graduate students, $20 \%$ for post-docs, $15 \%$ for international activities of students, and $20 \%$ for operations. No research funds and allowances for professors were allowed.

Professor's units were selected by size and league regardless of discipline including social science and the humanities. Under the principles of balanced regional development, the leagues of teams were divided into national and regional. Also large and small teams were divided. A large team is a department or a union of a department, and should have at least 10 professors, and also should be consisting of a minimum $70 \%$ of the whole department, or collaborating departments.

Master's students were given grants of a minimum 420 US dollars and doctorial students were given 760 dollars per month. Total grant size was not huge, but it was the largest grant to graduate schools in Korean history. Therefore, all universities were eager to receive the grants.

The selected reforms were more interesting and classified into two parts; there were plans for undergraduate reform and for relationship with industry. University reform had several objectives such as a cut-down on the number of undergraduate students towards research universities (large team), adopting a meritocracy for professors, and a set-up of entrepreneurial institutions. The cut-down of undergraduate students was imposed differently based on university status. For public universities a $15 \%$ cut on undergraduate students was imposed, and for private universities where student tuition is critical, other methods were used to cut down undergraduate student enrollment, such as a policy of the government to impose universities to hire at least $65 \%$ of the government recommended professor total which is based on student enrollment. This in effect controlled the amount of students a department can enroll, because more students would mean more mandatory hiring.

The second reform is the encouragement of industry ties by making industry or local governments match a minimum of 5\% to universities, to increase the number of technology transfers from universities, and by giving specialized courses to industry on technology transfer.

This reform is nearly identical with the direction of an entrepreneurial university except autonomy from government. This policy has no concerns about autonomy; therefore matters about autonomy are not discussed. 
Table 2 Overview of the BK21 Program

\begin{tabular}{|c|l|}
\hline & \multicolumn{1}{|c|}{ Contents } \\
\hline Purpose & World-class talents/university \\
\hline Type & Grants for graduate students/post-docs of selected teams \\
\hline Grant usage & $\begin{array}{l}45 \% \text { for direct grants, 15\% for post-docs } \\
\text { 20\% for internationalization activities } \\
20 \% \text { for management }\end{array}$ \\
\hline Supporting units & $\begin{array}{l}\text { By discipline (S\&T 88\% social science \& Humanities } \\
12 \%)\end{array}$ \\
& By size (union of department/department/team) \\
& By league (national/regional) \\
\hline Target-reform & $\begin{array}{l}\text { Reform of undergraduate (cut-down and M\&A) } \\
\text { Meritocracy for professors }\end{array}$ \\
& $\begin{array}{l}\text { University-industry linkage } \\
\text {-matching funds } \\
\text {-technology transfer }\end{array}$ \\
& -setting-up entrepreneurial institutions \\
\hline Target-graduate & $\begin{array}{l}\text { Enhancing research power (SCI papers) } \\
\text { school }\end{array}$ \\
& Internationalization of students \\
& Fostering university-industry linkage \\
\hline
\end{tabular}

Evaluation was done every year for simple checks and performance checks were done at the third year on four categories such as university reform, team management, budget, and output. Output is summarized as education, research, relationship with industry, and the targets of specialized teams who were assembled based on their special talents. Some teams failed at the $3^{\text {rd }}$ year evaluation.

\subsection{Extension of the Program}

Despite negative criticism at the early stage, overall evaluation showed more improvement than expected. Approximately 18,000 graduate students received grants along with 1,300 post-docs belonging to 120 large teams and 402 small teams with about 4,000 professors each year. Research output represented by SCI papers had grown to 18,497 with an improved world ranking of 13 by 2004 . Quality of students had been raised and graduate students could participate and present papers in international conferences. There was no problem of student employment after graduation. In addition, there was the intended effect of undergraduate reform such as a cut-down of undergraduate students at all participating universities and M\&A of similar departments. Moreover, there were several signs of the enhanced universityindustry relationship. 
Although the program was touted as "the best program for university reform" and showed promise on a micro basis, the public still criticized universities during the mid 2000s. Even the President criticized universities in a public speech on May 2006. The criticism at the time was summarized as follows: low level of international competitiveness by universities, no recognition of the threat of decreasing student enrollment, non-equilibrium of demand and supply of graduates between disciplines, and an oversupply of low level graduates. (Won, 2006)

Because of the good evaluation of the program itself and the social demand for university change, the program was extended for another seven years from 2006-2012, which is called the second stage of the BK21 Program. Although there is little difference between the $1^{\text {st }}$ and the $2^{\text {nd }}$ stages, the $2^{\text {nd }}$ can be said to have evolved from the $1^{\text {st }}$, covering the weakness of the $1^{\text {st }}$ stage. The weakness of the $1^{\text {st }}$ stage were high rates of distribution to Seoul National University, over emphasis on papers, low funding to basic science, and low development of the university-industry linkage. The team size and program budget in stage 2 is nearly identical to stage 1 .

The purpose of the $2^{\text {nd }}$ program was "fostering world-class talent." The target of the $2^{\text {nd }}$ program was to provide grants for 20,000 graduate students, obtain top 10 worldwide ranking in SCI papers, and increase the rate of technology transfer by universities from $10.1 \%$ of its total technology base in 2004 to $20 \%$ in 2012 . Also there were four strategic purposes in line with the official purpose: fostering research groups, building infrastructure for research universities, university-industry linkage, and fostering regional universities.

\section{Evaluation of the Program}

\subsection{Effects on Research}

All quantitative studies for research activities such as Kim, Na and Cho (2005), Kim, Lee (2005), Baek (2007) and Shin (2009) proved that there are clear research effects on participating teams and departments. In particular, Choi (2008) analyzed the increase in research by the physics department comparing participants and non-participants with similar conditions. In 2008, SCI papers reached 35,569 bringing Korea a world ranking of 12 .

Byun et al. (2011) showed the research performance of the program could be summarized as follows: SCI papers of BK21 participants in science and technology areas averaged 3.0 in 2009. The highest participants were GIST with 5.82 and 5.07 of POSTECH in 2009. Private universities produced more papers than public universities, but had a lower impact factor. Furthermore, 
papers and the impact factor in the science areas were better than other disciplines.

Research time of graduate students increased from an average of 45.4 to 61.8 hours per week, and papers from students (1.45) have increased more quickly than those of professors. As for internationalization, clear increases on short-term and long-term research travel abroad and increases of international collaboration were observed.

\subsection{Effects on University Structure}

One of the original targets for this program was university reform of research universities. One sample of change is Seoul National University, a flagship university in Korea. Around 2000, there was a ratio of 20 students to 1 professor, but dropped down to 15.9 to 1 by 2010. This level of ratio was intended to compete with Harvard University and top state universities of the US. Although this transformation of universities is not solely due to BK21, it is clear the program had big impact.

Table 3 Ratio of Professors to Students

\begin{tabular}{|l|l|r|r|r|r|}
\hline \multicolumn{2}{|c|}{} & \multicolumn{2}{|c|}{ Seoul National Univ. } & \multicolumn{1}{c|}{ Harvard } & Michigan \\
\cline { 3 - 6 } \multicolumn{2}{|c|}{} & \multicolumn{1}{|c|}{$(2010)$} & \multicolumn{1}{c|}{$(1999)$} & \multicolumn{1}{c|}{$(2000)$} & $(2000)$ \\
\hline \multirow{2}{*}{$\begin{array}{l}\text { Students } \\
\text { (a) }\end{array}$} & Undergraduate & 16,325 & 21,000 & 6,704 & 24,493 \\
\cline { 2 - 6 } & Graduate & 16,585 & 8,700 & 10,901 & 10,226 \\
\hline \multicolumn{2}{|c|}{ Professor (b) } & 2,074 & 1,485 & 2,300 & 2,633 \\
\hline \multicolumn{2}{|c|}{ (a/b) } & 15.9 & 20.0 & 7.7 & 13.2 \\
\hline
\end{tabular}

Sources: Moon \& Kim (2001) for earlier data, new data at www.academyinfo.go.kr

\subsection{Effects on Employment}

Studies looking into employment effects showed that there has been no negative effect on employment after graduation. Jang et al. (2006), Kwon et al. (2010), and Jang and Chon (2005) reported that more international experience and those with longer grants obtained higher salary. Byun et al. (2011) showed different effects on employment by discipline: clear positive effects for social science and the humanities, but no effects on graduates from science and technology.

Moreover, my interviews revealed further effects. The program has increased the number of science and technology students both in the team and whole nation, so saying "no problem after graduation" or "no clear change in employment" may mean increasing employment. Also, the quality of employment has increased. Even Master graduates from mid or low-mid level universities are employed as researchers. Graduates from mid to low-mid 
universities provide the basis of research manpower for a growing number of businesses and provide R\&D for small and medium firms.

\subsection{Other Effects}

There are different effects that run counter to the traditional culture and attitudes of a Korean University: increasing competition within universities, between universities, and increasing mobility of professors to better universities. Furthermore, BK21 has increased the concerns of policymakers on developing stronger research universities and on making world-class universities in Korea.

\subsection{Some Problems}

The policy casts many implications for designing research universities and university reform, but also it has raised some confusion as pointed out by Kwon et al. (2010). Although the explicit purpose of the program is bringing up high quality manpower, the real purpose seems to be university reform. This has made the execution of the program confusing as to whether the main target of the program is university reform or support for graduate students. Regardless, the multi-faceted nature of the program urged Korean universities to move towards the research university model.

Is the model based on fair competition and meritocracy? Is the budget responsible and suitable for the social sciences and humanities? All leaders of the program in the social sciences agree to the efficiency and effectiveness of the program, but the answers from those in the humanities tend to diverge. Scholars that were active participants seemed positive, but others disliked the policy.

Another issue known as the "straw effect" in Korea is that BK21 has sparked significant mobility of professors in Korea from regional universities into Seoul, the capital of Korea. Universities with big grants can absorb the best students and faculty, while universities with low budgets have a more difficult time getting grants, thereby making it difficult to attract students and professors.

Also, there appears to be an unprecedented problem. Because of the program's annual and mid-term evaluation, nearly all teams should measure the performance of participating professors. Therefore, information on performance has been open to all at the team level at participating universities. Previously, this transparency had been unheard of in Korean universities before the program. Prolific professors, however, have not wanted to boast about their performances, as this type of openness is still new within the university system. These professors produce much higher output than that of the average researcher on their team and against professors around the nation. 
This program has no functions to solve for this phenomenon, and there have not been enough incentives to accelerate the performance of best professors.

\subsection{Overall Evaluation of BK21 by Leaders}

The coverage of the program at the moment is quite deep and broad. "If this program did not exist, student enrollment at most graduate schools would have decreased by $1 / 3$ or $1 / 4$ the current student enrollment," said a leader at one leading university (Seol et al., 2011). This implies severe brain drain to universities of advanced countries could have occurred, if not for the success of BK21.

The budget of the program is only around 200-250 million US dollars per year, and the share among government R\&D budgets has been between 2.2$2.5 \%$ a year in recent times. Policymakers now evaluate the BK21 Program as "the best program with a minimal budget" for creating research universities, actualizing university reform, and providing a start for entrepreneurial universities.

Continuous grants for graduate students, although it is a minimal amount for each student, are better than any large R\&D project because supporting manpower is the key to research and innovation. During an interview, a professor at a regional national university stated to the author, "if there are graduate students without research funds, research can be completed by giving credit, but research is impossible even with large research funds if there aren't enough students."

\section{Discussions for Theory and Practice}

\subsection{What Factors made BK21 a Success?}

How could the program facilitate dramatic university reform? There is always resistance from professors and universities if government policies to universities contain compulsive or coercive orders. The late 1990s were a turbulent economic period because of the Foreign Exchange Crisis of 1997. The Korean government could urge reform during turbulent times creating opportunities reflecting the socio-economic environment. Importantly, the BK21 program became the first and largest grants program for graduate students in history during the aftermath of tough economic times. 


\subsection{What Type of Theoretical Model Program is this?}

Now let's discuss some issues on the policy model itself. First, is this policy model a pure creature of Korea? At the time of developing this policy from 1997 to early 1998, the idea of university capitalism by Slaughter \& Leslie (1997) and Clark (1998) had not reached Korean policy designers, and systems of innovation were only discussed between researchers (Lee at al., 1997). In addition, Min (1998) introduced a 1995 policy for graduate school written by the US Committee on Science, Engineering and Public Policy in late 1998. Song (2003) discussed the issues of graduate schools in recent times.

The concept of research universities, however, was a backbone of the designing team. The officer and designing team of the policy translated the book by Burton Clark written in 1995 (Ko et al., 1999). Furthermore, programs for graduate students in the United States became a model to emulate. The Integrative Graduate Education and Research Traineeship (IGERT) program started in the United States in 1998, in addition to the Graduate Research Fellowships Program since 1952. The BK21 program adopted the supportive policy of GRFP and IGERT to graduate students, adding more fundamental contents to university reform.

The IGERT program is intended to catalyze a cultural change in graduate education, for students, faculty, and institutions, by establishing innovative new models for graduate education and training in a fertile environment for collaborative research that transcends traditional disciplinary boundaries. IGERT awards are approximately \$3.0-3.2 million for a 5 year program, with the major portion of the funds being used for Ph.D. graduate student stipends of $\$ 30,000$ a year and training expenses. Since 1998 the IGERT program has made 260 awards to over 110 lead universities in 43 states, IGERT has provided funding for approximately 5,800 graduate students. (NSF, http:// www.igert.org/public/about)

BK21 has shown its limitations viewed under the framework of the entrepreneurial university or academic capitalism. Under the program, meritocracy has only been adopted at a few universities and entrepreneurship activities and education lag far behind American counterparts. Furthermore, some industry leaders still complain that the program did not do enough to strengthen the university-industry relationship. Regrettably, a study on the university-industry relationship of BK21 has not been conducted during the last 13 years.

Most respondents interviewed by the author, however, answered that there are considerable changes in the university-industry relationship from the program. Yet, it is still difficult to ascertain how far universities have gone towards the entrepreneurial university model or towards academic capitalism, except in the case of a few universities. This weak linkage between Korean 
universities and industry in general leads to a heavy dependence on government for financial support and policy.

BK21 did not develop under the framework of an entrepreneurial university, even though there has been considerable change. The program can be classified as supporting the research university model, although the program has stated that one of its purposes was to enhance university and industry linkage. The fact that a 13-year old policy constructed under the research university model had features of the entrepreneurial model shows the direction of change by current universities.

To further strengthen university and industry linkage policymakers will start a new program named LINC (Leaders in Industry-university Cooperation) for enhancing university-industry relationships in 2012. In addition, another policy for developing the WCU is currently underway.

Whatever the real purpose of BK21, the evaluation of this policy suggests that in developing countries, an entrepreneurial university cannot be formed by a policy developed for research universities. Even though this policy contains some objectives to achieve critical elements of the entrepreneurial university, it still has a long way to go into developing entrepreneurial universities.

\subsection{Role of Government in Developing Areas}

Hong Kong and Singapore are the early adopters among developing countries who recognized the changing trends towards the entrepreneurial university from the late 1990s. (Lee, Gopinathan, 2005; Mok, 2005; Wong, 2007) Both are small and open economies, but put great emphasis on high quality manpower. Their policies have been in the same direction as the core contents of university entrepreneurism. As a result, their policies are reflected in the ranking on WCU's as shown by Table 1 .

The announcement of world rankings on universities from the mid 2000's has made nearly all developing countries seek to develop good research universities and world-class universities. It is interesting that these discussions are shown in edited books from around the world, such as Zajda (2005), Altbach and Balan (2007), Yang and Welch (2011), Liu, Wang \& Cheng (2011), Goranson and Brundenius (2011).

Singapore and China are prime examples of aggressive reform to develop WCU's and Taiwan, Korea, and Japan follows. Honk Kong is somewhat exceptional compared to other countries since they are accustomed to the UK tradition of university autonomy, competition, and entrepreneurism.

European Union also has a deep concern for university reform. Brugel Institute, an EU think tank (Agion, Dewatripont \& Hoxby, 2007) reacted to world universities rankings and analyzed the status of EU universities using the Shanghai Jiao Tong Rankings. They concluded that the level of EU 
universities is far below that of the US. They identified the primary reason as 25 member countries only spend $1.3 \%$ of GDP on universities as compared to $3.3 \%$ in the US. Respectively, that equals to spending 10,000 Euro and 35,000 Euro per student every year.

Unlike university entrepreneurism of advanced countries, the WCU discussion in East Asia and the discussion of university reform on lessdeveloped countries appear to have the same issue: the role of government as one of the main drivers of reform. (Salmi, 2009, Salmi, Liu, 2011; Yang, Welch, 2011; Yonezawa, 2011) Although research universities and entrepreneurial universities are based on autonomy from government, the infrastructure for autonomy is still based on government policy in East Asian countries.

\section{Concluding Remarks}

This is a study on an old model of university reform in Korea based on current theoretical frameworks. What was the theoretical basis of BK21, and what are the limits of the policy? This research is based on the view that university reform is not only confined to those in higher education, but rather should be viewed in light of universities as being national systems of innovation, and a key factor for the modern growth and development of a nation.

This paper is a byproduct of giving a recommendation on designing a new policy successive to the Brain Korea 21 Program. Hence, it is based on futureseeking aspects: entrepreneurial universities in autonomy, universities as innovation for society and development, and world-class universities for edge in national competitiveness.

BK21 aimed to construct research universities by utilizing the scholarship of graduate students, although there were efforts to get benefits in line with the entrepreneurial university model. If the target of the program was confined to research universities, then it can be evaluated as successful. However, this policy had aspects that strove to be entrepreneurial, and if viewed from that perspective, our evaluation cannot give high credit on efforts to develop an entrepreneurial university.

Review of an old policy based on new theoretical frameworks gives rise to further questions. How many universities can become world-class in a nation? How many professors and research teams are needed to make a university world-class, thereby strengthening the competiveness of a country? Except some English speaking countries who traditionally have had strong universities, Northwestern European countries such as Sweden, Denmark, and the Netherlands put higher input into their universities, yielding more world- 
class universities then other nations in Europe. Should developing countries look there for finding a good model to create its own WCU's?

\section{Acknowledgements}

This research is supported by a research project requested by the Korea Research Foundation for the post-BK21 program and partially by the research fund of Hannam University, and based on a presentation at the International Conference on University Reform on November 11, 2011 at the 2011 Annual Fall Conference of the Korea Technology Innovation Society. 


\section{Reference}

Aghion, P., Dewatripont, M. Hoxby, C. et al. (2007) Why Reform Europe's Universities? Bruegel Policy Brief, September 2007(4), 1-8.

Altbach, P. G. (2004) The Costs and Benefits of World-Class Universities, Academe Online, 90-1.

Altbach, P., Baran, J. (2007) World Class Worldwide: Transforming Research Universities in Asia and Latin America, Baltimore, MD, Johns Hopkins University Press.

Barrow, C.W. (1996) The Strategy of Selective Excellence: Redesigning Higher Education for Global Competition in a Postindustrial Society, Higher Education, 31(4), 447-469.

Bercowitz, J., Feldman M. (2006) Entrepreneurial Universities and Technology Transfer, Journal of Technology Transfer, 31(1), 175-188.

Breschi, S., Malerba, F. (1997) Sectoral Innovation Systems: Technological Regimes, Schumpeterian Dynamics, and Spatial Boundaries, In C. Edquist (ed.), Systems of Innovation, 130-156, London: Pinter.

Byun, S. et al. (2011) A Study on Comprehensive Effect Analysis of BK21, Korea Research Foundation, April. (in Korean)

Chung, S., Seol, S. (2010) Stages and Drivers for the Development of Basic Scientific Research in Korea, Korea Technology Innovation Society Journal, 13(3), 587-616. (in Korean)

Clark, B. (1998) Creating Entrepreneurial Universities: Organizational pathways of Transformation, Oxford: International Association of University Press and Pergamon.

Cooke, P., (1998) Introduction: Origins of the Concepts, in H. Braczyk, P. Cooke \& M. Heidenreich, Regional Innovation Systems, London: UCL Press, 2-27.

Etzkowitz, H. (2004) The Evolution of the Entrepreneurial University, International Journal of Technology and Globalisation, 1-1, 64-77.

Etzkowitz, H., Leydesdorff, L. (1997) Introduction to Special Issue on Science Policy Dimensions of the Triple Helix of University-industry-government Relations, Science and Public Policy, 24(1), 2-5.

Etzkowitz, H., Leydesdorff, L. (2000) The Dynamics of Innovation: from National Systems and "Mode 2" to a Triple Helix of University-industry-government Relations, Research Policy, 29(2), 313-330.

Etzcowitz, H. et al. (2000) The Future of the University of the Future: Evolution of Ivory Tower to Entrepreneurial Paradigm. Research Policy, 29(2), 313-330.

Freeman, C. (1987) Technology Policy and Economic Performance; Lessons from Japan, Frances Printer Publishers: London.

Geiger, R. (1986) To Advance Knowledge: The Growth of American Research Universities 1900-1940, Oxford University Press.

Geiger, R. (1993) Research and Relevant Knowledge - American Research Universities since World War II, Oxford University Press.

Geiger, R. (2004) Knowledge \& Money: Research Universities and the Paradox of the Marketplace, Stanford University.

Gibbons, M. et al. (1994) The New Production of Knowledge, Sage Publications. 
Gibbons, M. (2000) Mode 2 Society and the Emergency of Context-sensitive Science, Science and Public Science, 27(3), 159-163.

Godin B., Gingras, Y. (2000) The Place of Universities in the System of Knowledge Production, Research Policy, 29(2), 273-278.

Göransson, B., Brundenius, C. (eds.) (2011) Universities in Transition, Springer.

Guerrero, M., Urbano, D. (2010) The Development of an Entrepreneurial University, The Journal of Technology Transfer.

Huisman, J. (2008) World-Class Universities, Higher Education Policy, 21, 1-4.

Jang, H., Chon, J. (2006) An Analysis of Transfer to Labor Market and Performance of Participants of the BK 21 Program, (in Korean)

Ko, Y. et al. (1999) Formation and Development of Research Universities, Seoul: Munum Publishing. (Korean Translation: Clark, B., 1995, Places of Inquiry: Research and Advanced Education in Modern Universities, California University Press.)

Kwon H. et al. (2010) Policy Implementation of the BK 21 Program: A Case of Social Science, Korea Administration Review, 19(3), 35-60.

Lee, M., Gopinathan, S. (2005) Convergence or Divergences? Comparing Education Reforms in Hong Kong and Singapore, International Handbook on Globalisation, Education and Policy Research, Part 1, 253-278.

Lee, K. R. et al. (1998) Korean National Innovation System, Science and Technology Policy Institute, Seoul. (in Korean)

Levin, R. (2010) The Rise of Asia's Universities, Foreign Affairs (May/June).

Liu, N. (2007) Research University in China: Differentiation, Classification, and Future of World-Class Status, in Altbach, P.G., Balan, J. (eds.), World-Class Worldwide-Transforming Research Universities in Asia and Latin America, Johns Hopkins University Press.

Lundvall, B. (ed.) (2002) National Systems of Innovation: Towards a Theory of Innovation and Interactive Learning, Printer Publishers.

Mars, M.M., Rios-Aguilar, C. (2010) Academic Entrepreneurship (Re)defined: Significance and Implications for the Scholarship of Higher Education, Higher Education, 59(4), 441-460.

Min, C.G (1998) Reshaping the Graduate Education of Science and Engineering, Korea Economic Daily, Seoul. (Korean Translation) US Committee on Science, Engineering and Public Policy, National Academy Press, 1995.

Ministry of Human Resources, Korea Research Foundation (2006) Master Plan of the $2^{\text {nd }}$ Stage BK21 Program, January. (in Korean)

Ministry of Human Resources (2007) White Paper of the BK 21 Program. (in Korean)

Mohrman, K. (2008) The Emerging Global Model with Chinese Characteristics. Higher Education Policy, 21, 29-48.

Mohrman, K., Ma, W. H., \& Baker, D. (2008) The Research University in Transition: The Emerging Global Model. Higher Education Policy, 21, 5-27.

Mok, K. H. (2005) Fostering Entrepreneurship: Changing Role of Government and Higher Education Governance in Hong Kong, Research Policy, 34(4), 537.

Nelson, R.R. (ed.) (1993) National Innovation Systems: A Comparative Analysis, Oxford University Press.

Pavitt, K. (2000.06) Academic Research in Europe, SPRU. 
Potts, A. (2011.04) Selling University Reform: the University of Melbourne and the Press, Studies in Higher Education.

Ramakrishna, S., Krishna, V. V. (2011), Emergence of Asian Universities as Centres of New Knowledge Generation and a Base for National Competitiveness - A Case Study of the National University of Singapore, in N. Liu, Q., Wang and Y., Cheng (eds.), Paths to a World-Class University-Lessons from Practices and Experiences, 2011, Totterdam/Boston/Taipei.

Reddy, P. (2011) The Evolving Role of Universities in Economic Development: The Case of University-Industry Linkages.

Rothaermal, F.T., Agung, S.D., Jiang, L. (2007) University Entrepreneurship: a Taxonomy of the Literature, Industrial and Corporate Change, 16(4), 691-791.

Salmi, J. (2009) The Challenge of Establishing World-Class Universities, World Bank, Washington D.C.

Salmi, J., Liu, N. (2011) Paths to a World-Class University, in Liu, N., Wang, Q and Cheng, Y. (eds.), Paths to a World-Class University- Lessons from Practices and Experiences, Totterdam/Boston/Taipei.

Seol, S. et al. (2011) A Study of Next S\&T Manpower Program based on the Analysis of Existing Programs of Korea Research Foundation, December. Korea Research Foundation.

Shin, J.C. (2009) Building World-Class Research University: The Brain Korea 21 Project, Higher Education, 58, 669-688.

Slaughter, S., Leslie, L.L. (1997) Academic Capitalism: Politics, Policies and the Entrepreneurial Universities, London: Johns Hopkins University.

Song, C. (2003) Fostering Research Competitiveness of Universities in Science and Engineering, Korea University Press. (in Korean)

Sporn, B. (2001) Building Adaptive Universities: Emerging Organisational Forms Based on Experiences of European and US Universities, Tertiary Education and Management, 7(2), 121-134.

Van der Ploeg, F. and Veugelers, R. (2008) Towards Evidence-based Reform of European Universities, CESifo Economic Studies, 54(2), 99-120.

Won, Y.J. (2006) Some Questions on the Second Stage of the BK21 Program, Munhwa Kwahak, 46, 262-273. (in Korean)

Wong, P.K (2007) Towards an "Entrepreneurial University" Model to Support Knowledge-Based Economic Development: The Case of the National University of Singapore, World Development, 35(6), 941-958.

Yang, R., Welch, A. (2011) A World-class University in China? - The Case of Tsinghua, Higher Education.

Yokoyama, K. (2006) Entrepreneurialism in Japanese and UK Universities: Governance, Management, Leadership, and Funding, Higher Education, 52(3), 523-555.

Yonezawa, A. (2011) The "Global 30" and the Consequences of Selecting "WorldClass universities" in Japan, in Liu, N., Wang, Q and Cheng, Y. (eds.), Paths to a World-Class University- Lessons from Practices and Experiences, Totterdam/ Boston/Taipei. 